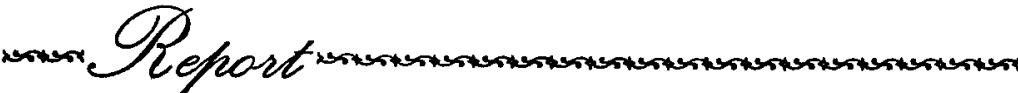 婁田基金補助による研究小集会報告
}

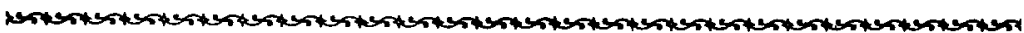

\section{楊 学成博士講演会}

世話人 岐帛大学膿学部 堀津浩章

平成 3 年 1 月 26 日（土）岐阜大学農学部 104 講義室 飞て藪田基金からの補助により中国黑竜江省科学院応用 改生物研究所所長 楊 学成博士の講演会が開催され， 盛況のららに講演を行うことができました．以下，講演 の要旨を述べる.

\section{[要旨]中国遗伝子操作研究分野の現状}

楊. 学成 (中国黒竜江省科学院応用微生物研究所)

最近十年来中国政府はバイオテクロジー分野をハイ テクサイエンスの重要な構成部分の一つと認めると共に 国民経済発展政策の一環として大いに支援してきた，そ れ故バイオテクノロジー分野の研究も著しい発展索遂げ た.ここではそのうち遭伝子操作研究分野の現状につ き，最近の主な成果を紹介する。

中国では農業と声接関係のある植物の遗伝子操作の研 究が比較的盛んに行われている. 陳章良（北京大学）ら はイネのウイルス病害の中, Tungro virus (TV) と Rice Dwarf virus (RDV) について分子生物学的研究を 行い，ウイルスおよびそのゲ/ムを純化，解析，分離，同 定した. RDV のゲ/ムは 12 本の二重鎖 RNA であり， そのらち4本の塩基配列を測定し、コードした RDVの $2 つ の$ 蛋白遗伝子を $35 \mathrm{~S}$ プロモーターにつなげて形質 転换植物に用いられるシステムを確立した，現在 TVか ら 1 個の遗伝子とRDVから2つの遗伝子をイネの幼肧 などの組織や細胞へ形質転換して，カルス培嚄拈よびト ランスジェニック苗への誘導実験を行っている。また， 范雲六（中国農業科学院）らは棉害虫に抵抗性の強い B. thuringiensisの殺虫性遗伝子を棉株に遒入して形質枟 換棉株を得た，それは非常に強い殺虫効果を示した。陳 章良らはをたウイルス耐性遺伝子と香料特改を持つ遺伝 子をタパコに形質転换して antivirus 性 flavouring 夕 ベという新品種開発に成功した． 300 万株の畑の実用
的テストで強いウイルス耐性を示し遗伝的形質も安定て 成長も良好であったという，それで作った巻タバコは特 別な香味を持ち，産業洒値も高いと期待している。一 方，方栄祥 (中国科学院微生物研) らは TMV と CMV カプシト蛋白遺伝子を同時に発現するとともに TMV と CMV に強い耐性を示才二価性抗ウイル タバュの選抜に成功して，畑の実用的テストで同型接合 体の選挍および遗伝子発現の解析を行った結果，泰用性 の高い、歷れた新品種であることを明らかにした，彼らは 同じく二优性抗ウイ心ス形質転換トマトの選抜を行い 28 株の再生トマトを得た，貫士栄（中国農業科学院）5 は抗菌ベプチド遺伝子 Cecropin B, $\mathrm{P}_{13}$ および Shiva プ ラスミドを持つ Agrobacterium tuteriferous と Agro bacterium hairizing を利用してポテトへの形質転換を 行いカナマイシン耐性再生株 24-5 株を得た.

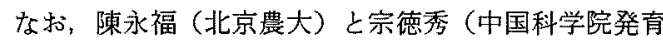
研）らの共同研究でブタのゲノムの成長遗伝子やcDNA を羊の MT-1 遺伝子プロモーターにつなき MT-PGH 組換えプラスミト゚を得，これをブタの受精卵に microinjection してィスブタの翰卵管の内部に移植した，乙 の結果人又豚 31 頭（移植肧胎数は 809）の中娃娠ブタ は21 頭，子プタ 136 頭中，生存した子豚は 116 頭て あり，その中トランスジェニック豚が 24 頭であった といら．朱作言ら（中国科学院・水生生物研）と沈孝宙 (中国科学院・動物研) はトランスジェニック魚の研究 を行い、コイの成長ホルモン遗伝子と MT-1 プロモー ター遗伝子と組又換えし，ドジョウ，コイおよびニジ スの受精卵に micro-injection して魚で発現させた。

去の浮か，中国科学院上海生化学研と生物製品研执よ び北京医科学院などの共同研究である $\mathrm{HBc}$ 抗原と HBs 抗原の遗伝子操作の研究成果はすでに丰用化され，臨休 に使われている。また，ヒト $\alpha$ なンターフェロンは遗 伝子操作の医楽品の中，中国で一番初めに免許を取った 製品であり，去年から臨床に応用され始めた。なお， と トのリンパ細胞のインターフェロン遗后子をクローニン グしてE.coli で効率よく発現させ，12 力所の大病院で 


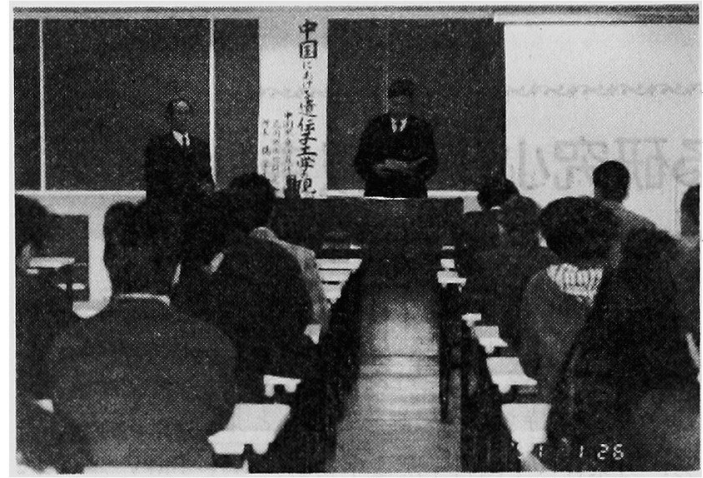

講演会場風景, 向かって右が講演者・楊学成氏, 左は通訳・金永煥氏

1000 以上の臨床応用の結果，有効率は $90 \%$ である. 刘 新垣ら (中国科学院上海生化研) はインターロイキン II (IL-2) 遗伝子の発現, 培羡・単離の研究を行い 4 種類の
PL プロモーターのベクターを組み換えし，これらを利 用して IL-2 を発現した. 生産量は菌体タンパク質の 35〜 40\% に至った. 単離した IL-2 の純度は $97 \%$ であ り，現在臨床寒験に投与している. 揚志興ら（黒竜江省 科学院・応用微生物研) は抗 B 型脳炎ウイルスのヒト・ マウスキメラ抗体遗伝子と抗ヒト胃癌モノクローナル抗 体遗伝子の分離, 純化, 組み換えおよび発現の研究をお こない, マウスの VH 遺伝子を得て, E. coli ベクターと 哺乳動物べククーとそれぞれ組み換えおよび発現させ た. そしてヒト・マウスキィラ抗体の発現産物を同定し た: 楊学成ら（黒竜江省科学院・応用微生物研）はサヶ の生長ホルモン遺伝子をクローニングして pRSV ベク ターと組み換えした．今, 魚への形質転換を試みている.

最後に, 本講演会開催にあたり，ご援助いたたききし た日本農芸化学会に感謝いたします.

\section{T. Norin 教授講演会}

世話人 森 謙治 (東京大学農学部)

日時：1991 年 2 月 20 日（水）午後 $3: 00 \sim 4: 30$

場所 : 東京大学農学部二号館農芸化学一番教室

題目: Enzymes and Bioorganic Transformations in Organic Synthesis

T. Norin 教授の講演会は 2 月 20 日（水）東大農学部 二号館で行われ, 学内外から約 50 名の参加者があっ た.スウェーデンにおける昆虫化学の第一人者で現在同 国化学会会長である教授は木喰虫を中心とするフェロモ ンの合成とその実際的応用など多くの研究で知られてい る. 今回は光学活性なフェロモンの合成のための原料調 製の手段として非常に有用な酵素などの生化学的手法の
利用について講演された. 中心となったのは加水分解酵 素であるリパービ, PLE, キモトリプシンなどに関する 話題である.

まず，酵素を用いる利点など基本的な問題について解 説したのち, 各種のエステル類を基質とした場合の基質 特異性，立体選択性に関する結果を述べた．次に酵素の 活性部位の構造と基質との反応性, 選択性についてコン ピニータグラフィックスを用いて解析した結果について 言及した，さらに加水分解を実際に行って，有用な基質 を光学活性体に変換した例を時間の許す限り述べた. 本 講演は酵素反応の物質レベルでの実際的な応用と共に理 論的解析についても言及したもので大变示唆に富むもの であったが未発表データも多く含まれており，今回は報 告に止めさせていただきたい.

本講演開催にあたりご援助いただいた，日本農芸化学 会に感謝する次第である.
植物脂質シンポジウム

一植物脂質 : その機能と代謝

世話人 市原謙一（京都府立大学農学部）

平成 3 年 3 月 27 日 (水), 京都府立大学図書館にて植 物脂質に関するシンポジゥムが開催された. 脂質は生体
膜の単なる構成成分として存在しているのみならず，さ まざまな生理的役割を担っている．植物に扮いては，た とえば葉緑体包膜に局在するホスファチジルグリセロー ルや液胞膜のスフィンゴ糖脂質の脂肪酸組成（分子種） は，その植物種の低温に対する感受性を決定する重要な 因子である.このような脂質の植物細胞における機能が 明らかにされるよらになってきたのは，ごく最近のこと であり, 過去 10 年間の植物脂質の生化学的, ならびに 